\title{
APPLICATION OF ISOTOPIC DILUTION AND SINGLE-STEP EXTRACTIONS FOR LABILE SOIL ZINC DETERMINATION
}

\author{
VLADIMÍR FRIŠTÁK, MARTIN PIPÍŠKA, \\ TATIANA GABLOVIČOVÁ, JURAJ LESNÝ
}

\author{
Department of Ecochemistry and Radioecology, University of SS. Cyril and \\ Methodius, J. Herdu 2,Trnava, SK-917 01,Slovak Republic (vladimir.fristak@ucm.sk)
}

\begin{abstract}
Concentration of available zinc from soils is the primary concern in assessment of its toxicity or essentiality for plants. This study evaluates the changes in chemical extractable $\mathrm{Zn}$ from three Slovak typical soils with simultaneous extractions as tools of zinc bioavailability. We found out that extractability of binding zinc decreased in order $\mathrm{Na}_{2}$ EDTA, Mehlich 3, Mehlich 2, $\mathrm{NH}_{4} \mathrm{NO}_{3}$ and $\mathrm{CaCl}_{2}$ for all soil samples. Using flow-through stripping chronopotentiometry (SCP) and atomic absorption spectrometry (GFAAS) we found out that maximum of soil zinc was removed by organic ligands. Lability of $\mathrm{Zn}$ determined by isotopic dilution method using ${ }^{65} \mathrm{Zn}$ and $\gamma$-spectrometry showed the significant decrease of isotopic exchangeable zinc fraction ( $E$-value) with decrease of soil reaction. Obtained $E$-values of uppermost soil horizons showed the zinc lability ranged from 20 to $39 \%$. Our research confirmed the effect of soil reaction, composition and physico-chemical characteristics to Zn lability. For further assessment of zinc bioavailability is needed to find the correlation and effects of structural changes and aging in studied soils.
\end{abstract}

Key words: soil, Zn, bioavailability, extraction, $E$-value

\section{Introduction}

Zinc is an essential trace element for the biological systems and is getting into the soil weathering of minerals and rocks forming the subsoil of the environment. Major form is divalent ion $\mathrm{Zn}^{2+}$ that is involved into sorption interactions of individual soil components. The increased concentrations of zinc can be potential risk of phytotoxicity. Many elements involved as trace elements at higher than optimal concentrations can be toxic (FRIŠTÁK et al., 2013). Soil contamination is not directly limited but can be reasonably associated with the negative anthropogenic effects as one of the major environmental problems. Generally, the mobility of trace metals in soils is a function of its chemical forms (VIJVER et al., 2003). Bioavailability may be defined as a fraction of metal that is available or can be made available for uptake of organisms (VAN GESTEL, 2008). Mobility and bioavailability of heavy metals in soil depend on their speciation or fractionation. LUOMA and RAINBOW (2005) showed factors of metals bioavailability such as soil characteristics, routes exposure and physiological attributes. Bioavailability can be also affected by the application of fertilizers and soil conditioners, which can significantly change the soil reaction $(\mathrm{pH})$, thus uptake of element by plants acceptors. Generally, the higher value of $\mathrm{pH}$ of the soil can cause more mobile and accessible elements forms for plant uptake (FRIŠTÁK et al., 2012).

As a tool for estimation and determination of bioavailable metals fraction and metal fractionation in soils are commonly used simultaneous and sequential extraction 
protocols as parts of fraction analysis. Non selectivity of extracting agents and redistribution of elements among phases during extraction are disadvantages of these methods (TESSIER et al., 1979). Despite a weak selectivity, chemical extraction methods are still often used to provide an understanding of mobility and bioavailability of metals (HULLEBUSCH et al., 2005). Direct methods have generally insufficient sensitivity for metal speciation analysis and give the quantity of metal ions in solution together with those in the solid phase which are in equilibrium with the dissolved metal ions. Therefore, determination of exchangeable metal fraction $(E$ value) represents quantification of ion pool from which ambient living organisms may take up the metal (STERCKEMAN et al., 2009).

The main aim of our paper was to describe distribution, leaching and bioavailability of zinc in soil samples from three typical Slovak areas by series of simultaneous extraction protocols. For obtaining of relevant data and comparing the method the isotopic dilution with ${ }^{65} \mathrm{Zn}$ was used.

\section{Materials and method}

\subsection{Experimental}

Available fractions of zinc in samples of soil extract were measured using flowthrough stripping chronopotentiometry. Experimental measurements were carried out on electrochemical analyser EcaFlow model GLP 150 (Istran, Ltd., Bratislava, Slovakia) equipped with electrochemical cell of type 104 with auxiliary, $\mathrm{Ag} / \mathrm{AgCl}$ reference and E-104L graphite porous working electrodes. Used parameters are given in Table 1. Obtained results were compared with reference values of GFAAS measurements by atomic absorption spectrophotometer Shimadzu AA-7000 (USA). For correction of background D2 lamp was used, after microwave digestion of the samples by the Multiwave system MW 3000 (Anton Paar GmbH, AUS). To calculate bioavailable zinc and obtain parameters of Paired $t$-test, ORIGIN 8.0 Professional (OriginLab Corporation, Northampton, USA) was used.

Table 1. Operation parameters of electrochemical determination of zinc by galvanostatic stripping chronopotentiometry analysis (SCP).

\begin{tabular}{lll}
\hline Parameter & Unit & Value \\
\hline Deposition potential & $\mathrm{mV}$ & -1800 \\
Quiescence potential & $\mathrm{mV}$ & -1800 \\
Quiescence time 1 & $\mathrm{s}$ & 5 \\
Quiescence potential 2 & $\mathrm{mV}$ & -1400 \\
Quiescence time 2 & $\mathrm{s}$ & 30 \\
Terminal potential & $\mathrm{mV}$ & 100 \\
Stripping current & $\mu \mathrm{A}$ & 200 \\
Stand by potential & $\mathrm{mV}$ & 0 \\
\hline
\end{tabular}

\subsection{Reagents and Solutions}

All the chemicals used were of analytical reagent grade. Deionized water $(<0,05 \mu \mathrm{S} / \mathrm{cm})$ prepared by Simplicity 185 (Millipore, France) was used for the 
preparation of all solutions. For electrochemical analysis, carrier electrolyte R-008 $\left(0.01 \mathrm{~mol} / \mathrm{L} \mathrm{CH}_{3} \mathrm{COOH}+0.01 \mathrm{~mol} / \mathrm{L} \mathrm{CH}_{3} \mathrm{COONa}+0.2 \mathrm{~mol} / \mathrm{L} \mathrm{NaCl}\right)$ and background electrolyte R-013 $(0.1 \mathrm{~mol} / \mathrm{L} \mathrm{HCl})$ were used. The bulk standard solution and calibration solutions of zinc were prepared in the background electrolyte from Certified Reference Material (999 mg/L ZnNO 3 , Sigma-Aldrich, Germany).

\subsection{Sampling and Sample preparation}

Three typical Slovak soil types were obtained from localities Jaslovské Bohunice (JB, Calcic Phaenozem), Sihla (S, Haplic Cambisol) and Borský Mikuláš (BM, Haplic Arenosol). The related sampling sites are shown in Figure 1. The samples were collected from horizon in depth of $0-20 \mathrm{~cm}$. Before the subsequent analytical procedures the soil samples were dried (at $22{ }^{\circ} \mathrm{C}$ ), homogenised and sieved through a 2 $\mathrm{mm}$ sieve. Samples were stored at dark and dry place.

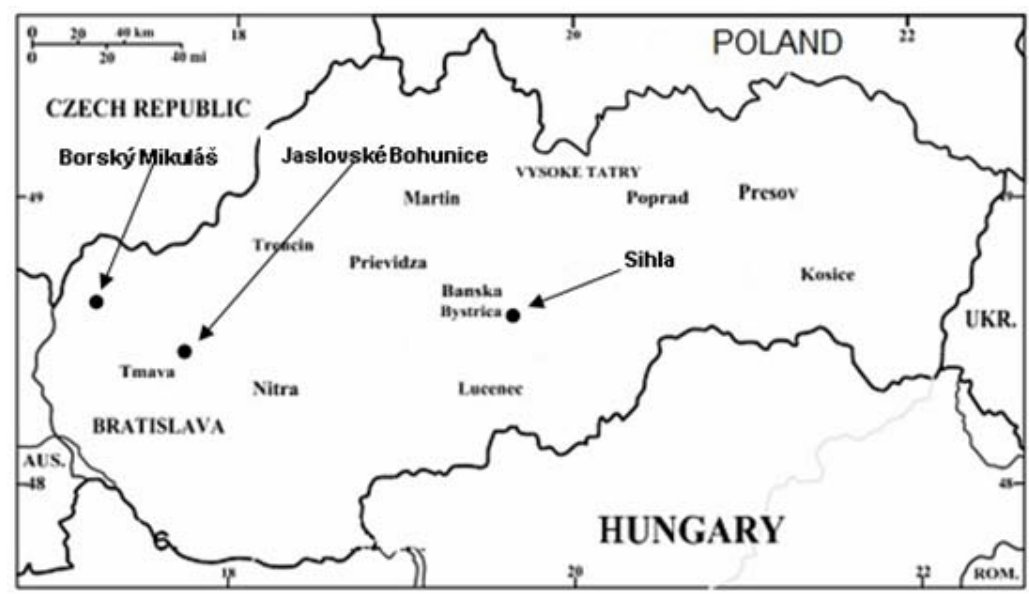

Fig. 1 Sampling sites of investigated soils.

\subsection{Physico-chemical characterisation of soil samples}

For actual soil $\mathrm{pH}, 5 \mathrm{~g}$ of air-dried soil samples was allowed to equilibrate in $25 \mathrm{ml}$ of deionised water. Flask was agitated on reciprocal shaker $(150 \mathrm{rpm})$ for $1 \mathrm{~h}$. To determine potential soil $\mathrm{pH}, 25 \mathrm{ml}$ of $1 \mathrm{~mol} / \mathrm{L} \mathrm{KCl}$ was added to $5 \mathrm{~g}$ of air-dried soil samples and allowed to equilibrate for $1 \mathrm{~h}$. After $1 \mathrm{~h}$ consolidation, $\mathrm{pH}$ values of supernatants were measured using a $\mathrm{pH}$ glass electrode (InoLab $\mathrm{pH} / \mathrm{ION} /$ Cond 750, WTW, France). Total carbonate content in soil samples was obtained by lime-analyser of own construction (GABLOVIČOVÁ et al., 2012). The cation exchange capacity (CEC) of samples was determined according to the STN ISO 11260 modified by FRIŠTÁK et al. (2013). Soil samples were suspended $(83.3 \mathrm{~g} / \mathrm{L})$ in $0.1 \mathrm{~mol} / \mathrm{L} \mathrm{BaCl}_{2}$ and mixed on a laboratory shaker for $1 \mathrm{~h}$ at $22^{\circ} \mathrm{C}$ and $150 \mathrm{rpm}$. Phases were separated after centrifugation ( $5 \mathrm{~min}$ at $5000 \mathrm{rpm}$ ). This procedure was repeated twice. The next 
step of CEC determination consisted of suspending of soil sediments in $3 \mathrm{ml}$ of 0.025 $\mathrm{mol} / \mathrm{L} \mathrm{BaCl}{ }_{2}$ and agitation for $19 \mathrm{~h}$ at $22^{\circ} \mathrm{C}$. After phases separation, $3 \mathrm{ml}$ of 0.02 $\mathrm{mol} / \mathrm{L} \mathrm{MgSO}_{4}$ was added to sediments. After agitation $\left(19 \mathrm{~h}\right.$ at $\left.22^{\circ} \mathrm{C}\right)$, centrifugation and phases separation, CEC by standardized $0.02 \mathrm{~mol} / \mathrm{L} \mathrm{Na} \mathrm{N}_{2}$ EDTA was determined. The CEC values were determined by chelatometric determination of $\mathrm{Mg}^{2+}$ ions in liquid phase and calculated according equation:

$$
C E C=\frac{\left(M_{0} V_{0}-M V_{v}\right) \varepsilon}{10^{-3}}
$$

where $C E C$ is cation exchange capacity (meq/100g), $M_{0}$ is molar concentration of magnesium added to the sample $(\mathrm{mol} / \mathrm{L}), V_{0}$ is volume of solution of magnesium added to the sample $(\mathrm{L}), M$ is molar concentration of the magnesium in the leachate $\left(\mathrm{mol} \mathrm{L}^{1}\right)$, $V_{v}$ is volume of obtained extract (L) and $\varepsilon$ is the conversion factor that has for the bivalent ions and amount $0.25 \mathrm{~g}$ of soil value $800 \mathrm{meq}(100 \mathrm{~g} / \mathrm{mol})$.

\subsection{Total (aqua regia extractable) Zn fraction}

Pseudo total soil content of zinc was estimated by aqua regia digestion $(3: 1, \mathrm{v} / \mathrm{v}$, $\mathrm{HCl}: \mathrm{HNO}_{3}$ ). This digestion procedure is considered adequate for analysing totalrecoverable heavy metals in soils (MEERS et al., 2007). Residual elements that are not released by aqua regia digestion are mostly bound to silicate minerals and are considered unimportant for estimating the mobility and behaviour of metals (NISKKAVAARA et al., 1997).

\subsection{Simultaneous extraction protocols}

Mobile $\mathrm{Zn}$-fractions were obtained after simultaneous extractions with $0.01 \mathrm{~mol} / \mathrm{L}$ $\mathrm{CaCl}_{2}, 1 \mathrm{~mol} / \mathrm{L} \mathrm{NH}_{4} \mathrm{NO}_{3}, 0.05 \mathrm{~mol} / \mathrm{L} \mathrm{Na}_{2} \mathrm{EDTA}$, Mehlich $2\left(0.2 \mathrm{~mol} / \mathrm{L} \mathrm{CH}_{3} \mathrm{COOH}+\right.$ $\left.0.2 \mathrm{~mol} / \mathrm{L} \mathrm{NH}_{4} \mathrm{Cl}+0.015 \mathrm{~mol} / \mathrm{L} \mathrm{NH}_{4} \mathrm{~F}+0.012 \mathrm{~mol} / \mathrm{L} \mathrm{HCl}\right)$ and Mehlich $3(0.2 \mathrm{~mol} / \mathrm{L}$ $\mathrm{CH}_{3} \mathrm{COOH}+0.25 \mathrm{~mol} / \mathrm{L} \mathrm{NH}_{4} \mathrm{NO}_{3}+0.013 \mathrm{~mol} / \mathrm{L} \mathrm{HNO}_{3}+0,015 \mathrm{~mol} / \mathrm{L} \mathrm{NH}_{4} \mathrm{~F}+0.001$ $\mathrm{mol} / \mathrm{L}$ EDTA). Extraction conditions of all cationic exchange and complexation procedures are given in Table 2.

Table 2. Extraction conditions of single-step extraction protocols used in experiments

\begin{tabular}{ccccc}
\hline Extraction solution & $\begin{array}{c}\text { E:S* } \\
\text { ratio }\end{array}$ & $\begin{array}{c}\text { Equilibration } \\
\text { time }[\mathbf{h}]\end{array}$ & $\mathbf{p H}$ & Reference \\
\hline $0.01 \mathrm{~mol} / \mathrm{L} \mathrm{CaCl}_{2}$ & $10: 1$ & 2 & 6 & DONNER et al. $(2010)$ \\
$1 \mathrm{~mol} / \mathrm{L} \mathrm{NH}_{4} \mathrm{NO}_{3}$ & $10: 1$ & 2 & 6 & MEERS et al. $(2007)$ \\
Mehlich 3 & $10: 1$ & 2 & 2.5 & MEHLICH (1984) \\
Mehlich 2 & $10: 1$ & 2 & 3 & MEHLICH $(1984)$ \\
$0.05 \mathrm{~mol} / \mathrm{L} \mathrm{Na} \mathrm{Na}_{2}$ EDTA & $10: 1$ & 2 & 3 & TICA et al. $(2011)$ \\
\hline
\end{tabular}

${ }^{*} \mathrm{E}: \mathrm{S}$ is a ratio between extractant phase and solid phase

Simultaneous extractable fractions were obtained by mixing of soil samples $(1 \mathrm{~g})$ with $10 \mathrm{ml}$ of extractant on laboratory shaker $(150 \mathrm{rpm})$ for $2 \mathrm{~h}$ at $22{ }^{\circ} \mathrm{C}$. After 
centrifugation (10 min, $8000 \mathrm{rpm}$ ), $5 \mathrm{ml}$ of supernatant was added to bank with 20-30 $\mathrm{ml}$ of reagent solution $\mathrm{R}-013$ and $0.5 \mathrm{ml} 0.01 \mathrm{~mol} / \mathrm{L} \mathrm{KMnO}_{4}$. The solution was heated to $80-95{ }^{\circ} \mathrm{C}$ for $5-10 \mathrm{~min}$. The oxalic acid was added to reduce the excess of permanganate. The volume of samples was adjusted to $50 \mathrm{ml}$ with the $\mathrm{R}-013$ reagent solution. Solid particles were removed by filtering, centrifugation or sedimentation. Zinc analysis in purified extracts was subsequently performed using stripping chronopotentiometry by electrochemical analyser EcaFlow model GLP 150 (Istran, Ltd., Bratislava, Slovakia). Obtained data were compared with data obtained by GFAAS analyse. All the analyses were carried out in triplicates.

\subsection{Isotopic dilution with ${ }^{65} \mathrm{Zn}$ (E-values)}

Isotopic dilution with ${ }^{65} \mathrm{Zn}$ was used to monitor changes in the labile $\mathrm{Zn}$ fraction over time. The procedure was based on the method of GOLDBERG and SMITH (1984) using $0.05 \mathrm{~mol} / \mathrm{L} \mathrm{CaCl}_{2}$ for displacement of soil zinc and top horizons of studied soils. To $2.5 \mathrm{~g}$ of soil samples, $25 \mathrm{ml}$ of $0.05 \mathrm{~mol} / \mathrm{L} \mathrm{CaCl}_{2}$ was added. To minimize the microbial activity, $0.1 \mathrm{ml}$ of $\mathrm{CHCl}_{3}$ was added. Flasks were agitated 5 days at $22 \pm 2{ }^{\circ} \mathrm{C}$ and $150 \mathrm{rpm}$. Calcium chloride increased the $\mathrm{Zn}$ concentration in solution, making its determination more precise. Process of chemical equilibrium was characterized by determination of exchangeable zinc in $5 \mathrm{ml}$ aliquots by galvanostatic stripping chronopotentiometry (SCP). These values were assigned to be the neutral salt extractable $\mathrm{Zn}$ concentration. The suspensions were subsequently spiked with $0.1 \mathrm{ml}$ of ${ }^{65} \mathrm{Zn}\left(\right.$ as $\mathrm{ZnCl}_{2}$ ) solution of $25 \mathrm{kBq} / \mathrm{ml}$ (Czech Institute of Metrology, Praque, Czech Republic). Spiked suspensions were shaken for 5 days. After centrifugation $(5 \mathrm{~min}$, $4000 \mathrm{rpm}$ ) radioactivity in $3 \mathrm{ml}$ of solid-free solution was measured by gamma spectrometric assembly using a well-type scintillation detector 54BP54/2-X, NaI(Tl) (Scionix, The Netherlands) and the data processing software Scintivision 32 (ORTEC, USA). All measurements were carried out in triplicates. The quantities of the isotopically exchangeable $\mathrm{Zn}$ in soil samples $\left(Z n_{E}\right)$ were calculated according to equation:

$$
Z n_{E}=\left(\frac{R_{s}}{r_{s}}\right) \cdot[Z n]_{s}
$$

where $R_{s}$ is radioactivity introduced in the suspension $(\mathrm{Bq} / \mathrm{kg} \mathrm{d.w}$.$) and r_{s}$ is the radioactivity measured in reaction solution at the end of experiment $(\mathrm{Bq} / \mathrm{kg}$ d.w.) and $[\mathrm{Zn}]_{s}$ is the mean concentration of extractable $\mathrm{Zn}$ in the soil extract as determined by $\mathrm{SCP}$ (mg/kg d.w.).

\section{Results and discussion}

The soil samples used in experiments varied widely in soil properties and characteristics (Table 3). Determination of soil $\mathrm{pH}$ noted the slightly acidic character of the soil sample S, and low alkaline character of soil sample JB. Soil reaction of soil sample BM varied between 5.9 and 6.8, depending on the method of determination. The sub-alkaline $\mathrm{pH}$ of JB sample, likely played a crucial role in reducing the $\mathrm{Zn}$ 
levels in soil solution. A decrease of $\mathrm{Zn}$ solubility with increasing $\mathrm{pH}$ has been reported by many authors (FRIŠTÁK et al., 2012; PARDO and GUADALIX, 1994; ZAMBELLA and ADAMO, 2010). Carbonate content was in the range from 0.5 to 0.7 in all soil samples. KIEKENS (1990) studied the reversibility of the exchange reaction between $\mathrm{Ca}$ and $\mathrm{Zn}$ and found that a key fraction of $\mathrm{Zn}$ was irreversibly bound by the soil components and following adsorption of $\mathrm{Zn}^{2+}$ and desorption of $\mathrm{Ca}^{2+}$ during $\mathrm{Zn}^{2+} / \mathrm{Ca}^{2+}$ exchange process. Associated with the wide range in soil texture, CEC value varied from 5.9 to $18.1 \mathrm{mmol} / 100 \mathrm{~g}$. Specific adsorption reactions, adsorption sites dependent on $\mathrm{pH}$ and reversibility of zinc binding may contribute to selective or major $\mathrm{Zn}$ adsorption (MAES, 1973). The determination of pseudo total zinc concentrations in studied soil samples by GFAAS analyses confirmed the increasing trend in order BM $<\mathrm{S}<\mathrm{JB}$. The uppermost parts of the rich soil on organic matter and humus contain increased concentration of heavy metals (GABLOVIČOVÁ et al., 2012).

Table 3. Physico-chemical properties of studied soil samples.

\begin{tabular}{cccccc}
\hline $\begin{array}{c}\text { Soil } \\
\text { sample }\end{array}$ & $\begin{array}{c}\text { Pseudo total } \mathbf{Z n} \\
{[\mathbf{m g} / \mathbf{k g}]}\end{array}$ & $\mathbf{p H}_{\mathbf{H} 20}$ & $\mathbf{p H}_{\mathbf{K C l}}$ & $\begin{array}{c}\mathbf{C E C} \\
{[\mathbf{m m o l} / \mathbf{1 0 0 g}]}\end{array}$ & $\begin{array}{c}\mathbf{C a C O}_{3} \\
{[\%]}\end{array}$ \\
\hline JB & 75 & 8.3 & 7.5 & 18.1 & 0.7 \\
$\mathrm{BM}$ & 12 & 6.8 & 5.9 & 5.9 & 0.5 \\
$\mathrm{~S}$ & 61 & 4.6 & 3.8 & 6.0 & 0.5 \\
\hline
\end{tabular}

Application of aqua regia extraction confirmed the lowest concentration of zinc $(12 \mathrm{mg} / \mathrm{kg})$ in BM soil samples obtained from haplic arenosol area with high content of calcium clays, dust, sand, conglomerate, coal beds and seams of lignite. Chemical extraction methods are widely used to assess the release of contaminants from soils, sludges, and sediments. As extracting agents in extraction procedures, strong acid and their mixtures $\left(\mathrm{HNO}_{3}, \mathrm{H}_{2} \mathrm{SO}_{4}, \mathrm{HCl}\right.$, aqua regia), neutral solution of salts $\left(\mathrm{CaCl}_{2}\right.$, $\left.\mathrm{MgCl}_{2}, \mathrm{NaCl}\right)$, pending puffer and complex-forming agents $\left(\mathrm{Na}_{2}\right.$ EDTA) can be used (MEERS, 2007). However, no single method is recognized universally (TICA et al., 2011). Available zinc concentrations, expressed as a pore water concentration or concentrations extractable with agent of ion exchange were lower in comparison with other tested extracting agent (Figure 2a). The other extraction protocols can be used for the assessment of potentially toxic metals released from soils to the water recipients and their potential availability to all biological systems (MCLAUGHLIN et al., 2000). For determination of soil zinc mobile fractions 5 extracting agents were used. We tried to quantify the zinc content in extracts using stripping chronopotentiometry. Zinc was deposited on porous electrode from acidic solution with high efficiency dependent on deposition potential.

Obtained data were compared to values from GFAAS as reference method (Figure 2b). Coefficient of determination $\left(r^{2}\right)$ of linear correlation was 0.998 and it showed the comparability of used analytical methods. Paired t-test also confirmed nonsignificance of differences between used methods and thus statistical significance of obtained data of extractable zinc $(\alpha=0.05)$.

The extractability of $\mathrm{Zn}$ obtained with the $\mathrm{NH}_{4} \mathrm{NO}_{3}$ protocols was in general higher than that obtained with the $\mathrm{CaCl}_{2}$ protocols for all soil samples. Low alkaline sample 
JB released $\mathrm{Zn}$ easily in reaction system of $\mathrm{NH}_{4} \mathrm{NO}_{3}$ in comparison to studied acidic agents. Effect of this extraction protocol can be attributed to the possible complexation of $\mathrm{Zn}$ by $\mathrm{NH}_{3}$ (LEBOURG et al., 1998) and higher ionic strength of extracting agent. Extraction efficiency of acidic agents increased in order Mehlich 2, Mehlich 3 and $\mathrm{Na}_{2}$ EDTA for all soil samples. Chelating effect of used extraction agent caused significant increasing of extractable zinc from exchange sites, carbohydrate and organic matter [9]. We confirmed the extraction efficiency of organic ligands on wide range of soil components.
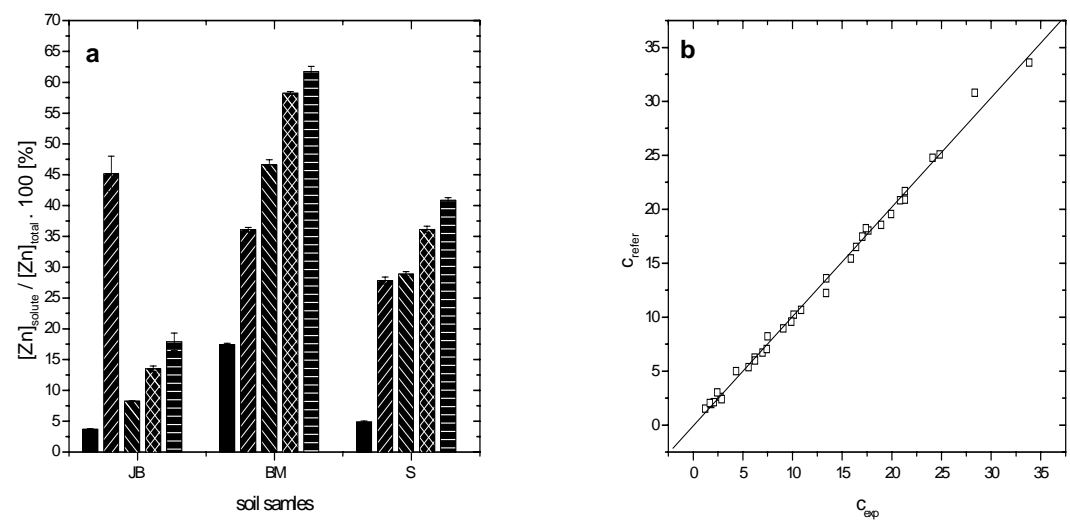

Fig. 2. Efficiency of simultaneous extraction protocols of zinc $(\mathrm{mg} / \mathrm{kg})$ from the three soil samples (JB, BM, S). Extraction conditions: $2 \mathrm{~h}, 22^{\circ} \mathrm{C}, 150 \mathrm{rpm}, 100 \mathrm{~g} / \mathrm{L}$, extracting agents: $\mathrm{CaCl}_{2}(\mathbb{\square}), \mathrm{NH}_{4} \mathrm{NO}_{3}(\mathbb{Z})$, Mehlich $2(\mathbf{W})$, Mehlich $3(\mathbf{X}), \mathrm{Na}_{2}$ EDTA (可). All experiments were carried out in triplicates. Error bars represent standard deviation of the mean $( \pm \mathrm{SD})$ (a). Comparison obtained concentrations of extractable zinc determined by electrochemical analyses $\left(\mathrm{c}_{\exp }\right)$ with reference values determined by GFAAS analyses $\left(\mathrm{c}_{\mathrm{ref}}\right)$ (b).

NAIDU and HARTER (1998) showed that metal extracted by a mixture of organic acids is well-correlated with the mobile metal fraction in the soil solution. Metal fraction extracted by organic acids is more available for biological system compared to other complexing agents. Low molecular weight organic acids such as ethylene diamine tetraacetic acid (EDTA) and their salts $\left(\mathrm{Na}_{2}\right.$ EDTA) were reported to remove metals organically bound, occluded in oxides, and associated with secondary clay minerals (PAYA-PEREZ et al., 1993). Effect of soil reaction was less significant. We found out that simultaneous extraction protocols had maximal efficiency for low acidic soil sample of Haplic Arenosol (BM). Thus we confirmed the effect of soil composition as a parameter of zinc availability from this typical Slovak soil.

For next investigation of labile or potentially available $\mathrm{Zn}$ fraction in the studied soil samples, the isotopic dilution ( $E$-value) was used. The studied samples of uppermost horizons contain the highest pseudo total concentration of zinc. The $E$ values reported in Table 4 show how much the $\mathrm{Zn}$ in soil samples was isotopically exchangeable within experimental equilibrium period. Zinc availability in three soil samples ranged from 20 to $39 \%$. These values were comparable with concentrations of $\mathrm{Na}_{2}$ EDTA extractable zinc. DEGRYSE and SMOLDERS (2006) reported $E$-values of 
zinc equivalent to $32-49 \%$ lability in upper horizons of acid soils ( $\mathrm{pH} 3.3-4.5)$. On the other hand, DONNER et al. (2010) showed the exchangeable fraction of zinc in the range from 12 to $15 \%$ for agricultural soils with $\mathrm{pH}$ from 5 to 6.6 .

Our study confirmed decreasing concentration of labile soil zinc with increased soil reaction of samples in order Haplic Cambisol, Haplic Arenosol and Calcic Phaenozem. Measurements by radioisotope dilution with ${ }^{65} \mathrm{Zn}$ demonstrate a significant of soils $\mathrm{pH}$ and variation of $\mathrm{Zn}$ bioavailability depending on soil type and physic-chemical characteristics. Further work is needed to assess the importance of soil amendments and long-term ageing in terms of zinc bioavailability.

Table 4. E-values of soil samples JB , BM and S depending on $\mathrm{pH}$ and total $\mathrm{Zn}$ concentration [mg/kg]. All experiments were carried out in triplicates, mean $\pm \mathrm{SD}$.

\begin{tabular}{cccc}
\hline & \multicolumn{3}{c}{ Soil sample } \\
\cline { 2 - 4 } pH & JB & BM & S \\
\cline { 2 - 4 } Total Zn [mg/kg] & 8.3 & 6.8 & 4.6 \\
Zn E-value [mg/kg] & $75.0 \pm 6.0$ & $12.0 \pm 0.9$ & $61.0 \pm 4.7$ \\
Labile Zn [\%] & $15.1 \pm 1.9$ & $2.51 \pm 0.2$ & $23.8 \pm 1.3$ \\
\hline
\end{tabular}

\section{Conclusions}

As tools of available zinc fraction determination, single-step extraction methods can be used. Our paper confirmed the effect of physico-chemical properties $(\mathrm{pH})$ of soil samples and applied extraction protocol to extractable zinc concentration. We found out that extractability of binding zinc decreased in order $\mathrm{Na}_{2}$ EDTA, Mehlich 3, Mehlich 2, $\mathrm{NH}_{4} \mathrm{NO}_{3}$ and $\mathrm{CaCl}_{2}$ for studied soil samples. Flow-through stripping chronopotentiometry (SCP) and atomic absorption spectrometry (GFAAS) confirmed the maximum of removable soil zinc by organic ligands. Lability of soil $\mathrm{Zn}$ can be determined by isotopic dilution method using radioactive isotope ${ }^{65} \mathrm{Zn}$ and $\gamma$ spectrometry. Determination showed the significant decrease of isotopic exchangeable zinc fraction ( $E$-value) with decrease of soil reaction. $E$-values of studied soil samples showed the zinc ability in range from 20 to $39 \%$. Our study confirmed the effect of soil reaction, composition and physico-chemical characteristics to $\mathrm{Zn}$ lability.

Acknowledgment: This work was financially supported by University of SS. Cyril and Methodius in Trnava (project FPPV-01-2013).

\section{References}

FRIŠTÁK, V., PIPÍŠKA, M., HORNÍK, M., AUGUSTÍN, J., LESNÝ, J.: Sludge of wastewater treatment plants as $\mathrm{Co}^{2+}$ ions sorbent. Chem. Pap., 67, 2013, 265-273.

VIJVER, M.G., VINK, J.P.M., MIERMANS, C.J.H., VAN GESTEL, C.A.M.: Oral sealing using glue: a new method to distinguish between intestinal and dermal uptake of metals in earthworms. Soil Biol. Biochem., 35, 2003, 125-132.

VAN GESTEL, C.A.M: Physico-chemical and biological parameters determine metal bioavailability in soils. Sci. Total Environ., 406, 2008, 385-395. 
LUOMA, S.N., RAINBOW, P.S.: Why is metal bioaccumulation so variable? Biodynamic as a unifying concept. Environ. Sci. Technol., 39, 2005, 1921-1931.

FRIŠTÁK, V., VALOVČIAKOVÁ, M., PIPÍŠKA, M., AUGUSTÍN, J.: Simultaneous and sequential extraction protocols as tools for determination of zinc bioavailability in dried anaerobic sludge. Nova Biotechnol. Chim., 11, 2012, 167175.

TESSIER, A. CAMPBELL, P.G.C. BISSON, M.: Sequential extraction procedure for the speciation of particulate trace metals. Anal. Chem., 51, 1979, 844-851.

HULlEBUSCH, E.D., UTOMO, S., ZANDVOORT, M.H., LENS, P.N.L.: Comparison of three sequential extraction procedures to describe metal fractionation in anaerobic granular sludges. Talanta, 65, 2005, 549-558.

STERCKEMAN, T., CARIGNAN, J., SRAYEDDIN, I., BAIZE, D., CLOQUET, C.: Availability of soil cadmium using stable and radioactive isotope dilution. Geoderma, 153, 2009, 372-378.

GABLOVIČOVÁ, T., NÁDASKÁ, G., LESNÝ, J.: Contribution to Mn bioavailability assessment in characteristic soil types via $E$-value determinations. Acta Agron. Óvár., 54, 2012, 17-28.

MEERS, E., DU, L.G., UNAMUNO, V., RUTTENS, A., VANGRONSVELD, J., TACK, F.M.G., VERLOO, M.G.: Comparison of cadmium extractability from soils by commonly used single extraction protocols. Geoderma, 141, 2007, 247259.

NISKAVAARA, H., REIMANN, C., CHEKUSHIN, V., KASHULINA, G.: Seasonal variability of total and easily leachable element contents in topsoils $(0-5 \mathrm{~cm})$ from eight catchments in the European Arctic (Finland, Norway and Russia). Environ. Pollut., 96, 1997, 261-274.

DONNER, E., BROOS, K., HEEMSBERGEN, D., WARNE, M.S.J., MCLAUGHLIN, M.J., HODSON, M.E., NORTCLIFF, S.: Biological and chemical assessments of zinc ageing in field soils. Environ. Pollut., 158, 2010, 339-345.

MEHLICH, A.: Mehlich-3 soil test extractant: a modification of Mehlich-2 extractant, Comm. Soil Sci. Plant Anal., 15, 1984, 1409-1416.

TICA, D., UDOVIC, M., LESTAN, D.: Immobilization of potentially toxic metals using different soil amendments. Chemosphere, 85, 2011, 577-583.

GOLDBERG, S.P., SMITH, K.A.: Soil manganese: $E$ value, distribution of manganese 54 among soil fractions, and effects of drying. Soil Sci. Soc. Am. J., 48, 1984, 559-564.

PARDO, M.T., GUADALIX, M.E.: Chemical factors affecting selenite sorption by allophanic soils. Geoderma, 63, 1994, 43-52.

ZAMPELLA, M., ADAMO, P.: Chemical composition and Zn bioavailability of the soil solution extracted from $\mathrm{Zn}$ amended variable charge soils. J. Environ. Sci., 22, 2010, 1398-1406.

KIEKENS, L.: Heavy Metals in Soils, Blackie USA and Canada Halsted Press, New York, 1990.

MAES, A.: Ion exchange of some transition metal ions in montmorillonites and synthetic faujasites, Doctoral Thesis, Louvain, 1973. 
MCLAUGHLIN, M.J., HAMON, R.E., MCLAREN, R.G., SPEIR, T.W., ROGERS, S.L.: Review: a bioavailability-based rationale for controlling metal and metalloid contamination of agricultural land in Australia and New Zealand. Aust. J. Soil Res., 38, 2000, 1037-1086.

LEBOURG, A., STERCKEMAN, T., CIESIELSKI, H., PROIX, N.: Trace metal speciation in three unbuffered salt solutions used to assess their bioavailability in soil. J. Environ. Qual., 27, 1998, 584-590.

NAIDU, R., HARTER, R.D.: Effects of different organic ligands on cadmium sorption and extractability from soils. Soil Sci. Soc. Am. J., 62, 1998, 644-650.

PAYA-PEREZ, A., SALA, J., MOUSTY, F.: Comparison of ICP-AES and ICP-MS for the analysis of trace elements in soil extracts. Int. J. Environ. Anal. Chem., 51, 1993, 223-230.

DEGRYSE, F., SMOLDERS, E.: Mobility of $\mathrm{Cd}$ and $\mathrm{Zn}$ in polluted and unpolluted Spodosols. Eur. J. Soil Sci., 57, 2006, 122-133. 